Bingöl Üniversitesi
İktisadi ve İdari Bilimler Fakültesi Dergisi
Bingol University
Cournal of Economics and Administrative Sciences
Cilt/Volume: 5, Say1/Issue: 2
Yil/Year: 2021, s. 191-213
DOI: 10.33399/biibfad.878430
ISSN: 2651-3234/E-ISSN: 2651-3307
Bingöl/Türkiye
Makale Bilgisi/Article Info
Gelis/Received: 11.02.2021 Kabul/ Accepted: 20.10 .2021

\title{
THE EFFECTS OF THE COVID-19 PANDEMIC ON THE CAREER GOAL FEEDBACKS OF UNIVERSITY STUDENTS*
}

\section{Covid-19 Pandemisinin Üniversite Öğrencilerinin Kariyer Hedefi Geri Bildirimlerine Etkileri}

\section{Seher UÇKUN** Aysen ŞİMŞEK KANDEMİR***}

\begin{abstract}
This study aims to reveal the effects of the fear of the Covid-19 pandemic on university students' career goals. The quantitative method was utilized in the research, and an online survey method was applied to 352 participants. The scales were tested for validity and reliability. Reliability was found to be 0.909 for the Career Goal Feedback Scale (CGFS) and 0.861 for the fear of pandemic. Since our variables were categorical, the relationships between Career Goal Feedback (CGF) and independent variables were examined with the chi-square test. The CGF Scale composed of 24 items and the Fear of Pandemic Scale composed of six items were employed. It was examined whether statistically significant differences existed between demographic characteristics and the fear of pandemic and CGFS. Subdimensions of CGFS were constructed using exploratory factor analysis (EFA), and the effect of the fear of pandemic on Career Goal Feedback (CGF) was analyzed by multinomial logistic regression analysis. As a result of the analysis, the differences found between education level, program, and fear of pandemic and CGF were statistically significant.
\end{abstract}

\footnotetext{
* Ethical approval for this study was obtained from Kocaeli University Humanities and Social Sciences Research Ethics Committee (Date: 24.07.2020 / No: 52506)

** Doç.Dr., Kocaeli University, Ulaştırma Yüksekokulu, seher.uckun@gmail.com, ORCID: https://orcid.org/0000-0002-7840-2363

*** Doç.Dr. Kocaeli University, Hereke ÖİU MYO, kandemir_aysen@hotmail.com, ORCID: https://orcid.org/0000-0001-5020-1183
} 
According to the multinomial logistic regression analysis, it was concluded that the fear of pandemic had a statistically significant effect on CGF.

Keywords: Career, career goal, COVID-19, multinomial logistic regression

JEL Codes: M12; C30; C38

\section{Öz}

$\mathrm{Bu}$ çalışmanın amacı pandemi korkusunun üniversite öğrencilerinin kariyer hedefleri üzerindeki etkisini ortaya koymaktır. Çalışmada nicel araştırma yöntemi kullanılmıştır. Araştırmada, 352 katılımcıya online olarak anket yöntemi uygulanmıştır. Ölçeklere geçerlilik ve güvenirlik testi yapılmıştır. Kariyer Hedefi Geribildirim Ölçeği (KHGBÖ) için güvenirlik 0.909 ve pandemi korkusu için ise 0.861 olarak bulunmuştur. Değişkenlerimiz kategorik olduğu için KHGB ile bağımsız değişkenler arasındaki ilişki ki-kare ile test edilmiştir. 24 maddeden oluşan KHGBÖ ile 6 maddeden oluşan pandemi korkusu ölçeği kullanılmıştır. Demografik özelliklerle pandemi korkusu ve KHGBÖ arasında istatistiksel olarak anlamlı bir fark olup olmadığı test edilmiştir. Faktör analizi kullanılarak KHGBÖ ne ait alt boyutları oluşturulmuş olup ve multinominal lojistik regresyon analizi ile pandemi korkusunun kariyer bildirimi geri bildirimi Kariyer Hedefi Geri Bildirimi (KHGB) üzerindeki etkisi analiz edilmiştir. Analiz sonrasında eğitim düzeyi, programı ve pandemi korkusu ile KHGB arasında istatistiksel olarak anlamlı bir farklılık çıkmıştır. Multinominal lojistik regresyon analizi sonrasında pandemi korkusunun KHGB üzerinde istatistiksel olarak etkili olduğu sonucuna ulaşılmıştır.

Anahtar Kelimeler: Kariyer, kariyer hedefi, COVID-19, multinominal lojistik regresyon

JEL Kodları: M12; C30; C38

\section{Introduction}

People begin to receive an education with the influence of their families and the effects of socio-cultural, economic, and environmental factors. People can be considered to have made a career start in the education process, especially during high school and university education. The decisions they make from then on are about what the individuals want to do in their lives. A career is a person's responsibility; they continue to work in a job thanks to the knowledge 
and skills they have acquired as a result of the education, or they work in another profession outside of their education.

According to WHO (World Health Organization), a pandemic is considered to have begun in case of the emergence of a disease that the population has not been exposed to before, the transmission of the pathogenic agent to humans and causing a dangerous disease, and the spread of the causative agent among people easily and continuously (WHO, 2020). These symptoms have increased rapidly all over the world as of December 2019. The coronavirus (COVID-19) pandemic was officially announced by WHO on March 11, 2020 (Zhang, Hu and Ji, 2020: 1). After it emerged in China, the Covid-19 outbreak had an impact upon the entire world in such a short while like three months (Budak and Korkmaz, 2020: 62). The pandemic has caused an impending economic crisis and stagnation around the world, selfisolation (staying at home), physical distancing, travel restrictions, a shrinkage in the workforce in all the sectors of the economy, and countless job losses. On the other hand, while the requirement for medical supplies has increased outstandingly, the food industry has faced increasing demand because of panic purchasing and food stockpiling. Due to the global epidemic happening now, socioeconomic differences have emerged between individuals all over the world (Nicola et al., 2020: 185). Therefore, individuals' expectations for the future have been affected.

In the present research, the impact of the current pandemic on setting individual career goals and getting feedback was examined from the perspective of university students.

\section{Career, Career Goal, and Career Feedback}

Nowadays, the concept of career is defined more broadly than word meaning (Ertürk, 2011: 201). Some definitions related to career are as follows. Career is often expressed as career promotion, gaining a certain status, and career advancement (Sabuncuoğlu, 2008: 168). A career is a series of jobs that continue throughout an individual's life by undertaking the authorities and responsibilities related to his/her job in accordance with his/her knowledge and skills (Kaynak et al., 2000: 230). As career concept has both individual and organizational 
aspects, individuals also plan their personal career goals while they realize the objectives of the organization (Akdoğanl1, 2019: 3). Career is a concept that covers progress, pause, and regression in the lifelong professional development process (Mavisu, 2010: 6).

Career goals can be expressed as the path an individual will follow in his/her future working life (Korkmaz and Kirdök, 2019: 495). An individual who has a career goal would notice the opportunities in his/her environment to achieve his/her goal and would exhibit a behavior pattern accordingly (Zajas and Zajas, 1994: 8).

Feedback is considered as one of the strongest impacts on learning and success; however, the said impact might be positive or negative (Hattie and Timperley, 207: 81). Feedback provides information to an individual to be able to see if a goal is a success or not. According to Bandura (1991), getting feedback about the result of a goal would increase an individual's motivation. Career goal feedback supplies data concerning the suitability of career goals, the effectiveness of the progression towards a goal, and whether alterations are required to achieve the goals (Hu, Creed and Hood, 2017: 657). Career goal feedback can be external (such as the parents of a student, his/her teachers, and fellow students) and internal (such as inner feelings and reflections originating from intuition and social comparison). CGF increases motivation for individuals to progress towards their career goals and enables them to self-regulate their career processes (Butler and Winne, 1995: 247; Hu, Creed and Hood, 2017: 658).

Previous studies encountered when reviewing the literature on career goal feedback are presented below.

In their study about the significance of career goal acting as a mediator in the career feedback and career-induced stress relationship, $\mathrm{Hu}$, Hood and Creed (2016) discussed the negative CGF and careerinduced stress relationship. They questioned whether career goalperformance discrepancy worked as a mediator in the said relationship, then they evaluated whether the significance of career goal intensified the indirect impact of the negative feedback. In their research, they concluded that negative feedback was positively correlated with stress, besides, this discrepancy served as the 
moderator of the said relationship. A sample consisting of 317 health professions university students with an average age of 19.5 years was employed in the study. It was concluded that for individuals who had higher goal importance, the discrepancy was also higher at higher negative feedback levels, and negative feedback had an indirect effect on stress through discrepancy.

Developing a measure to evaluate CGF, Hu, Creed and Hood (2017) conducted an initial verification study in order to determine the situations that indicate which external and internal feedback had a significant role in career development. They designed an inventory with 24 items to be applied to young adults. They utilized the EFA method to examine the factor structure along with the confirmatory factor analysis (CFA) and provided evidence for validity. In this study, EFA was applied to 531 participants and CFA to 524 participants for career goal feedback. While the average age of the EFA group was $19.19 \pm 1.33$ and $42.5 \%$ were male, the average age of the CFA group was $19.16 \pm 1.28$ and $36.6 \%$ were male. As a result of the EFA, it was determined that the data were suitable for EFA since $\mathrm{KMO}=0.90$ and Bartlett's test $\mathrm{p}<0.001$. According to the model fit indices obtained after CFA, the scale was accepted as valid. The explained variances were $28 \%$ for stress and $15 \%$ for self-efficacy, respectively. As a result of the study, the correlations between socioeconomic status, age, gender, year in university, and rural university entrance score were found to be negligible $(r=|0.01-0.03|)$.

In their research about the within-person relationship between career-induced stress and CGF based on a weekly survey, Hu, Hood and Creed (2018b) examined the mechanisms underlying the withinperson relationship between career-induced stress and negative CGF. With its sample consisting of young adults (a weekly survey study was used with a sample of young adults and four measurements [212 observations]), the research emphasized that career feedback and optimism had a significant role in the career self-regulation of young people.

In their study discussing negative career feedback (NCF), career outcomes, and the mediating functions of self-regulatory processes, 
$\mathrm{Hu}$, Hood and Creed (2018) tested a self-regulation model by a survey with 413 Chinese university students (out of a total of 459 young adults, 46 questionnaires with erroneous data were excluded from the analysis). In the study employing a six-point Likert scale, $57.9 \%$ of the participants were women; average age $=19.01$ years; $\mathrm{SD}=1.13$; and $64.9 \%$ were first-year students. Utilizing SEM, the study discussed that self-regulatory processes (career self-efficacy, career stress, and career goal commitment) would play an intermediary role for the relationship of negative feedback with career exploration and career goal shifting. As a result of the research, goal commitment and stress served as a mediator for the positive directional links from career feedback on goal suitability (CI95: $0.16-0.61$ and $0.01-0.27$, respectively; indirect effects $=0.25$ and 0.08 , respectively) and improvements needed (CI95: $0.01-0.09$ and 0.01 - 0.09, respectively; indirect effects $=0.07$ and 0.07 , respectively) to goal shifting (total effect $=0.30$ for goal suitability and 0.25 for improvements needed). Goal commitment also acted as a mediator between negative feedback on progress and goal shifting (C195: between -0.09 and -0.01 ; indirect effect $=-0.05$; total effect $=-0.22$ ), and stress, on the other hand, did not have a significant mediating influence (CI95's included zero). Besides, it was found that only career self-efficacy mediated the association between negative feedback on progress and exploration (C195: between -0.21 and -0.03 ; indirect effect $=-0.11$; total effect $=$ -0.16 ). They discussed three kinds of NCF (about progress, the suitability of goals, and required improvements) and self-regulatory processes-cognitive (self-efficacy), affective (career stress), and motivational (goal commitment). According to their hypothesis, it was revealed that receiving more negative feedback about the suitability of goals and required improvements was associated with a higher rate of career goal shifting through a higher level of career-induced stress and a lower level of commitment to career goals. However, they stated that, contrary to their hypothesis, more progression-related negative feedback was associated with a lower rate of career goal shifting through a higher level of goal commitment and associated with a lower rate of career exploration through a lower level of career self-efficacy. 
In their study with 344 participants, $61 \%$ of whom were female and $39 \%$ male, Jawahar and Shabeer (2019) inquired how NCF had an impact on career goal disengagement and discussed the mediating roles of career planning and psychological well-being. They stated that, as suggested by the social cognitive model of career selfmanagement, adverse career feedback would cause individuals to reevaluate their career goals. Based on a study conducted by $\mathrm{Hu}, \mathrm{Hood}$ and Creed, they hypothesized that NCF would trigger cognition in the manner of career planning and it would influence it in the manner of well-being, and then career planning and psychological well-being would provide information for the decision to disengage from or reengage with career goals. They obtained solid proof for the mediating effect of career planning and psychological well-being, and they concluded that, against the presuppositions, there was a negative relationship between NCF and career goal disengagement $(r=-0.35$, $\mathrm{p}<0.001)$. A moderately strong negative relationship was detected between Negative Career Feedback and Psychological Well Being $(\mathrm{r}=$ $-0.43, \mathrm{p}<0.001)$, and a moderately strong positive relationship between Negative Career Feedback and Career Planning $(r=0.48, \mathrm{p}<0.001)$.

Although there are numerous publications about the pandemic, no study could be found about career goals. Even though several articles and papers have been published around the world and in our country about the health dimension of the pandemic, the most comprehensive study in Turkey was conducted by the Turkish Thoracic Society; since the beginning of the COVID-19 pandemic, they have made summary translations by compiling articles on the subject from the world medical literature. Apart from studies on other subjects (such as tourism, finance, accounting, education, psychology, socioeconomics, etc.), studies regarding university students are summarized below.

In their research conducted with 112 participants from 36 provinces, Dönmez and Gürbüz (2020) examined the cognitive structures of associate degree and undergraduate students regarding the Covid-19 virus. $58 \%$ of the participants were associate degree students and $42 \%$ were undergraduate; $74 \%$ of them were female and $26 \%$ were male. As a result of the study, it was noticed that the participants' cognitive structures regarding the Covid-19 concept were concentrated on 
perception, the cause of transmission, and the ways of protection, and besides, they had some misconceptions. When they were asked about the sources of trust regarding Covid-19, authorities ranked first with the highest rate of $78 \%$, and doctors ranked second with $12 \%$. When the participants were asked about the management of the Covid-19 pandemic emergency and how individuals and institutions were conducting the works, $79 \%$ of the participants stated that they positively evaluated the performances of the Ministry of Health and similar institutions.

Çetin and Anuk (2020), in their study with 109 students, including $75 \%$ female and 25\% male, assessed the relationship between loneliness and psychological resilience amongst university students throughout the coronavirus (Covid-19) outbreak. As a result of the research, it was ascertained that there was no relationship between gender, loneliness, and psychological resilience. They observed that there was a negative and weak relationship between loneliness and psychological resilience. Furthermore, it was determined that the data obtained from the questions about students' thoughts regarding the country and their future, not being able to meet their basic needs in the future, general life satisfaction, and what the first thing they would like to do when the epidemic was over was made a difference in the loneliness and psychological resilience of the students. When asked how the performance changed after distance education due to Covid$19,74.3 \%$ of the students stated that the performance decreased, and $76.1 \%$ of the students stated that online education should not become widespread in Turkey. The study showed that with a death in the inner circle and family due to Covid-19, a statistically significant difference emerged between the psychological resilience of the students and the loneliness experienced by the students $(t=-2.472, p=0.015 ; t=3.43, p$ $=0.01$ ).

In a study in which a total of 52 university students, 33 of whom were female $(63.5 \%)$ and 19 (36.5\%) were male, participated, Baltac1, Akbulut and Zafer (2020) examined university students' experiences concerning their internet usage during the COVID-19 pandemic. Their study revealed that a great majority of the university students had difficulty in controlling their internet usage during the COVID-19 
pandemic, and their usage of the internet negatively affected their relationships with other family members, caused problems in their social interactions, however, had positive influences on their academic lives. As a result of the qualitative research; 4 of the students stated that they spent an average of 1-3 hours a day on the Internet during the COVID-19 pandemic, 17 of them spent 3-5 hours, and 31 of them spent an average of more than 5 hours a day. Besides, one of the students stated that the internet made life predominantly difficult during the COVID-19 pandemic, 22 of them stated that it had a moderate effect, and 29 of them stated that the internet made their lives easier.

Islam et al., (2020), in their study conducted with the participation of a total of 476 university students living in Bangladesh, investigated the widespread presence of depression and anxiety among Bangladeshi university students in the course of the coronavirus (COVID-19) outbreak. The data were examined at three sequential levels, including univariate, bivariate, and multivariate analysis. They concluded that approximately $15 \%$ of the students had moderate depression, while $18.1 \%$ suffered from severe anxiety. The binary logistic regression revealed that older students suffered higher levels of depression $(\mathrm{OR}=2.886,95 \% \mathrm{CI}=0.961-8.669)$. It was also observed that students who gave private lessons before the pandemic experienced depression $(\mathrm{OR}=1.199,95 \% \mathrm{CI}=0.736-1.952)$.

In their research, Gonzalez et al., (2020) analyzed the impacts of the coronavirus lockdown on university students' performance in terms of autonomous learning. Applying a field test with the participation of 458 students attending three different majors at the Universidad Autónoma de Madrid in Spain, they divided the students into two groups and analyzed the differences in assessments. The results showed that the COVID-19 lockdown produced a significant and positive impact on the performance of the students.

Byrnes et al., (2020), in their study based on the analysis of 1.668 responses collected through an online survey administered to students at US allopathic medical schools between April 13, 2020, and April 30, 2020, examined the COVID-19 pandemic in the USA and, as a 
consequence, how it affected the career perceptions of medical students. As a result, they observed that nearly one-fifth (337 respondents [20.2\%]) of the medical faculty students surveyed thought, for the moment, that the outbreak of coronavirus would influence their specialty choices, and most of them expressed their concerns that they would not be able to explore specialties or get letters of recommendation. Differences among class years were found to be significant: $15.2 \%$ (53) of the first-year students, $26.4 \%$ (92) of the second-year students, $23.7 \%$ (162) of the third-year students, and $9.7 \%$ (22) of the fourth-year students $(\mathrm{p}<0.0001)$.

\section{Method}

\subsection{The Purpose and Importance of the Research}

First identified in December 2019 in Wuhan, China, the first case of the new type of coronavirus (covid-19) pandemic was reported in Turkey on March 11, 2020, and the start of the global pandemic was announced by the World Health Organization on the same date. From this date, efforts have been made to get the pandemic under control by taking various measures both in Turkey and all over the world. The covid-19 virus causes two types of health problems, including physical health problems and pandemic-induced mental health problems (Aşkın, Bozkurt and Zeybek, 2020). When the literature was reviewed, a significant increase was observed in the number of recent studies regarding the Covid-19 pandemic. However, we think that this study will fill a considerable gap, due to the limited number of researches about the effect of the pandemic, particularly on young people's thoughts about the future.

\subsection{Research Method}

In addition to the participants' demographic characteristics, this research utilized the Career Goal Feedback Scale (CGFS) consisting of 24 items, which was studied by Korkmaz and Kirdök (2019) in terms of validity and reliability in Turkish, and the Fear of Pandemic Scale consisting of six items, which was used by Bakioğlu, Korkmaz, and Ercan in the study conducted in 2020, were utilized. The purpose of the research was to reveal the effects of the fear of the pandemic on 
university students' career goals. The data obtained on the internet over approximately three months were evaluated statistically. First of all, the survey participants' demographic characteristics were probed. Afterward, the existence of statistically significant differences was investigated between demographic characteristics and the fear of pandemic and CGFS. Subdimensions of CGFS were constructed using factor analysis, and finally, the effect of the fear of pandemic on career goal feedback (CGF) was analyzed by the multinomial logistic regression method. Ethical approval for this study was obtained from Kocaeli University Humanities and Social Sciences Research Ethics Committee (Date: 24.07.2020 / No: 52506).

\subsection{Results}

Based on the data obtained, participants' demographic characteristics, fear of pandemics, and the distribution of the data acquired according to CGFS subdimensions are presented in Tables 1 , $2,3,4$, and 5 .

Table 1: Survey Participants' Demographic Characteristics

\begin{tabular}{lccc}
\hline & & Frequency & $\%$ \\
\hline \multirow{2}{*}{ Gender } & Male & 121 & 34.4 \\
& Female & 231 & 65.6 \\
\hline \multirow{4}{*}{ Age } & $18-20$ & 207 & 58.8 \\
& $21-23$ & 113 & 32.1 \\
\multirow{2}{*}{ Education Type } & $24-26$ & 15 & 4.3 \\
& $27+$ & 17 & 4.8 \\
\hline \multirow{3}{*}{ Education } & Formal Education & 203 & 57.7 \\
& Evening Education & 149 & 42.3 \\
\hline \multirow{4}{*}{ Program } & Associate & 251 & 71.3 \\
& Undergraduate & 99 & 28.1 \\
& Graduate & 2 & 0.6 \\
\hline \multirow{4}{*}{ Year } & Vocational School/Technical & 125 & 35.5 \\
& Vocational School/Social & 127 & 36.1 \\
& Undergraduate/Technical & 79 & 22.4 \\
& Undergraduate/Social & 8 & 2.3 \\
& Undergraduate/Health & 11 & 3.1 \\
& Graduate & 2 & 0.6 \\
\hline
\end{tabular}


Table 2: Distribution Regarding the Fear of Pandemic

\begin{tabular}{lcc}
\hline \multicolumn{1}{c}{ Fear of Pandemic } & Frequency & \% \\
\hline Never & 104 & 29.5 \\
Sometimes & 199 & 56.5 \\
Always & 49 & 13.9 \\
\hline
\end{tabular}

According to Table 2, 56.5\% of the university students stated that they sometimes experienced the fear of pandemic, and $13.9 \%$ of them stated that they always did.

In Tables 3, 4, and 5, the distribution of the data obtained as specified by the 5-point Likert Scale (Strongly Disagree, Disagree, Undecided, Agree, Strongly Agree) is presented in a 3-point arrangement (Disagree, Undecided, Agree) only for frequency distributions, considering the ease of interpretation.

Table 3: Distribution of Answers Regarding the Motivation for Career Goal

\begin{tabular}{lcc}
\hline \multicolumn{1}{c}{ Motivation } & Frequency & $\%$ \\
\hline Disagree & 156 & 44.3 \\
Undecided & 139 & 39.5 \\
Agree & 57 & 16.2 \\
\hline
\end{tabular}

Here, since the questions in the CGFS were negative feedback, $44.3 \%$ of the university students participating in the study told that they disagreed with the negative thought stated for motivation regarding their career goals. On the other hand, $16.2 \%$ of them answered following the negative opinion about motivation.

Table 4: Distribution of Answers concerning Knowing What They Should Do for Their Career Goals

\begin{tabular}{lcc}
\hline \multicolumn{1}{c}{ Knowing What They } & Frequency & $\%$ \\
\hline Should Do & 206 & 58.5 \\
Uisagree & 103 & 29.3 \\
Andecided & 43 & 12.2 \\
\hline
\end{tabular}

According to Table 4, as the questions in CGFS were negative feedback, $58.5 \%$ of the university students participating in the study, expressed that they disagreed with the negative thought stated about knowing what to do towards their career goals. As for the $12.2 \%$, they 
reflected the viewpoint that they did not know what to do about their career goals.

Table 5: Distribution of Answers Regarding the Suitability of Career Goals for the Individual

\begin{tabular}{lcc}
\hline \multicolumn{1}{c}{\begin{tabular}{c} 
Suitability for the \\
\multicolumn{1}{c}{ Individual }
\end{tabular}} & Frequency & $\%$ \\
\hline Disagree & 220 & 62.5 \\
Undecided & 113 & 32.1 \\
Agree & 19 & 5.4 \\
\hline
\end{tabular}

According to Table 5, 62.5\% of the university students participating in the research stated that their career goals were suitable for the individual, and $5.4 \%$ stated that they were not.

In CGFS, possible scores would occur between 24 and 120. Among the questions, 22 of which were negatively and two of which were positively constructed, two questions belonging to the positive opinion were reverse scored. High scores indicate that students do not show behaviors compatible with their career goals (Korkmaz and Kirdök, 2018). In our study, the total score occurred as 61.02, revealing that individuals, on average, showed behaviors consistent with career goals. According to the results of the factor analysis for CGFS: the feedback was divided into two as coming from the individual and his/her environment; and for the career goal, a total of six dimensions emerged with the internal and external feedbacks for the dimensions of progress and motivation towards career goals, knowing what to do for career goals and suitability of career goals for the individual. This situation resulted in line with the validity and reliability examination of the original scale that was conducted by adapting to Turkish. In the present study, the feedbacks from the individual and his/her environment were not taken into account, and the analysis was conducted by examining three dimensions.

According to the results of the factor analysis, the percentage of the total variance was found to be $67.940 \%$ for the six dimensions that emerged as in the original scale. When the CGFS was evaluated as three dimensions, the total variance was $50.295 \%$, and the factor loadings of two questions (which were within the dimension of what 
to do for career goal) were excluded from the analysis due to their low factor loads. In the factor analysis repeated for the remaining 22 items:

The total variance was found to be $52.228 \%, \mathrm{KMO}=0.878$ and Bartlett's Test $=3606.925, \mathrm{p}=0.000$. Kaiser-Meyer-Olkin Test $(\mathrm{KMO})$ value was almost perfect, indicating that the data set was highly suitable for factor analysis, and Bartlett's Test exhibited that significant correlations existed among variables in the correlation matrix, i.e., the data set was suitable for factor analysis.

The Cronbach a coefficient, which indicated whether the items in the CGFS represented a whole with a homogeneous structure, was found to be 0.909 , which confirmed that the scale was highly reliable. Reliability was tested separately for each subdimension, and Cronbach's alpha values were obtained as follows: for the dimension "progress and motivation towards career goal", Cronbach's a = 0.859; for the dimension "knowing what to do for career goal", Cronbach's a $=0.818$; and for the dimension "suitability of career goals for the individual", Cronbach's $a=0.834$. These results revealed that the internal consistency reliabilities of the subdimensions produced nearly excellent results. The Cronbach's a value of the items used to measure the fear of pandemic was obtained as 0.861 , and it was determined that the reliability of the said scale was considerably high.

Applying multinomial logistic regression, it was investigated whether the pandemic had an impact on the career goals of the students experiencing uncertainty about their education and training with the emergence of the Covid-19 outbreak in our country.

\subsection{Multinomial Logistic Regression Analysis}

In multivariate analysis methods, when the dependent variable is measured with a nominal scale, the estimates obtained using the Least Squares Method remain incapable (Kalayc1, 2009). While the LS technique assumes that the dependent variable is normally distributed, this assumption cannot be provided in the case of a nominal scale. For the logistic regression analysis that is used as an alternative in case the dependent variable is nominal, the dependent variable must be dichotomous (with two categories). In the case of 
three or more categories, multinomial logistic regression analysis examines the cause-effect relationship between the dependent variable and the independent variables, thus it is viewed as an extended version of the binary logistic regression analysis for more than three categories (Ar1, 2016). If the dependent variable has a "j" number of categories, i.e., when "j" is considered as 3 categories coded as " 0 ", " 1 ", and " 2 ", two logistic models will be established. When " 0 " is taken as the reference (baseline) category, these logistic models will be $\mathrm{y}=1$ versus $\mathrm{y}=0$ and $y=2$ versus $y=0$ (Bayram, 2004). Where $y=0$ is the reference category, the logistic function comparing $\mathrm{y}=2$ versus $\mathrm{y}=1$ is equal to the difference of the logistic functions of the binary comparison expressed above. The general expression of conditional probabilities is achieved in equation 1 using the logistic functions given as follows (Bayram, 2004). In the functions given below, the reference category is taken as "y $=0 "$.

$g_{1}(x)=\ln \left[\frac{P(y=1 \mid x)}{P(y=0 \mid x)}\right]=\beta_{10}+\beta_{10} x_{1}+\beta_{12} x_{2}+\cdots+\beta_{1 p} x_{p}=x^{\prime} \beta_{1}$

$g_{2}(x)=\ln \left[\frac{P(y=2 \mid x)}{P(y=0 \mid x)}\right]=\beta_{20}+\beta_{20} x_{1}+\beta_{22} x_{2}+\cdots+\beta_{2 p} x_{p}=x^{\prime} \beta_{2}$

$\mathrm{P}(y=0 \mid x)=\frac{1}{1+e^{g_{1(x)}+e^{g_{2(x)}}}}$,

$\mathrm{P}(y=1 \mid x)=\frac{e^{g_{1(x)}}}{1+e^{g_{1(x)}+e^{g_{2}(x)}}}$

$\mathrm{P}(y=2 \mid x)=\frac{e^{g_{2(x)}}}{1+e^{g_{1(x)}}+e^{g_{2(x)}}}$ and

$\mathrm{P}(y=j \mid x)=\frac{e^{g_{j(x)}}}{\sum_{k=0}^{2} e^{g_{k(x)}}}$

For parameter estimates in multinomial logistic regression, the logarithm of the conditional likelihood function of the " $n$ " sample size is taken, and the likelihood function presented below is obtained.

$$
\begin{aligned}
& L(\beta)=\ln [l(\beta)]=\sum_{i=1}^{n} y_{1 i} g_{1}\left(x_{i}\right)+y_{2 i} g_{2}\left(x_{i}\right)-\ln (1+ \\
& \left.e^{g_{1}\left(x_{1}\right)}+e^{g_{2}\left(x_{1}\right)}\right)
\end{aligned}
$$

The likelihood equations are obtained through taking the first partial derivatives of $L(\beta)$ and setting them equal to zero.

When $\pi_{j i}=\pi_{j}\left(x_{i}\right)$, the general representation of these equations is as below:

$$
\frac{\partial L(\beta)}{\partial L \beta_{j k}}=\sum_{j=1}^{n} x_{k i}\left(y_{j i}-\pi_{j i}\right)
$$


With this information, the second partial derivative matrix of the likelihood function given in equation 2 is used in order to acquire the estimator of the covariance matrix of the maximum likelihood estimator.

\subsection{Application}

In this study, CGF consists of five categories for multinomial logistic regression, whose theoretical structure is described, and gender, age, education type, education level, program, year, and the fear of pandemic are taken as independent variables. First, as a result of the chi-square test administered between the CGF and independent variables, the results given in Table 6 below were obtained.

Table 6: The Results of the Chi-Square Test Applied between CGF and Independent Variables

\begin{tabular}{llcc}
\hline \multicolumn{1}{c}{ Variables } & $\chi^{2}$ & p \\
\cline { 2 - 4 } CGF & Gender & 1.453 & 0.835 \\
& Age & 18.860 & 0.92 \\
& Education Type & 3.926 & 0.426 \\
& Education Level & 16.087 & 0.041 \\
& Program & 44.105 & 0.001 \\
& Year & 24.767 & 0.074 \\
& Fear of Pandemic & 19.744 & 0.011 \\
\hline
\end{tabular}

When Table 6 was examined, a statistically significant difference was identified between CGF and the students' education levels, programs, and fear of pandemic at a significance level of 0.05 . The likelihood ratio test was performed for the variables of education level, program, and the fear of pandemic, which emerged significantly according to the chi-square test, with CGF, and the test results are given in Table 7.

Table 7: The Results of the Likelihood Ratio Test

\begin{tabular}{llccc}
\hline \multirow{6}{*}{ CGF } & $\begin{array}{c}\text { Variables Examined } \\
\text { for Effect }\end{array}$ & $\begin{array}{c}\text {-2 Log Likelihood of } \\
\text { Reduced Model }\end{array}$ & $\boldsymbol{\chi}^{\mathbf{2}}$ & $\mathbf{p}$ \\
\cline { 2 - 5 } & Constant & 413.274 & 11.301 & 0.023 \\
& Education Level & 408.117 & 6.144 & 0.189 \\
& Program & 415.848 & 6.397 & 0.171 \\
& Fear of Pandemic & 413.140 & 13.876 & 0.008 \\
\hline
\end{tabular}


The relationship between the fear of pandemic and CGF, which was found significant according to the likelihood ratio test results, was estimated by multinomial logistic regression analysis; the results are displayed in Table 7. According to the results of the likelihood ratio test of the established model: the likelihood ratio was obtained as $\chi^{2}=$ $20.168, p=0.010$, and it was determined that the model was fit. The goodness of fit of the model was found to be $p=0.159$, and it was determined that the model was well-fitting for the data.

In the parameter estimates displayed in Table 8, "Strongly agree" was taken as the reference category for CGF and "Always" for the fear of pandemic.

Table 8: Parameter Estimates

\begin{tabular}{lcccccc}
\hline \multicolumn{1}{c}{ CGF } & $\begin{array}{c}\text { Fear of } \\
\text { Pandemic }\end{array}$ & B & $\begin{array}{c}\text { St. } \\
\text { error }\end{array}$ & Wald & p & Exp(B) \\
\hline \multirow{3}{*}{ Strongly Disagree } & Constant & -0.857 & 0.319 & 7.227 & 0.007 &. \\
& Never & 1.058 & 0.450 & 5.522 & 0.019 & 2.881 \\
& Sometimes & 1.339 & 0.423 & 10.034 & 0.002 & 3.816 \\
\hline \multirow{2}{*}{ Disagree } & Constant & -1.012 & 0.337 & 9.005 & 0.003 &. \\
& Never & 1.340 & 0.457 & 8.585 & 0.003 & 3.819 \\
& Sometimes & 1.334 & 0.442 & 9.097 & 0.003 & 3.798 \\
\hline \multirow{3}{*}{ Undecided } & Constant & -0.164 & 0.257 & 0.409 & 0.523 &. \\
& Never & 0.107 & 0.425 & 0.064 & 0.801 & 1.113 \\
& Sometimes & 0.487 & 0.385 & 1.602 & 0.206 & 1.628 \\
\hline \multirow{2}{*}{ Agree } & Constant & -0.361 & 0.272 & 1.766 & 0.184 &. \\
& Never & 0.562 & 0.418 & 1.805 & 0.179 & 1.754 \\
& Sometimes & 0.535 & 0.402 & 1.766 & 0.183 & 1.708 \\
\hline
\end{tabular}

When Table 8 was examined, the fact that students "never" or "sometimes" had the fear of pandemic was determined to be effective on the students' thoughts of "strongly disagreeing" with a negative opinion towards their career goals. In terms of a negative opinion towards their career goals, the probability of a student strongly disagreeing with this opinion rather than strongly agreeing with it is 2.881 times higher for those who do not have pandemic fear than those who express that they always have this fear. In other words, those who are afraid of the pandemic are more likely to experience negative emotions towards their career goals. Again, if the students sometimes experience the fear of pandemic instead of always, the likelihood of 
disagreeing with a negative opinion about their career goals is 3.816 times more than the likelihood of agreeing with that negative opinion.

Likewise, the fact that students "never" or "sometimes" had the fear of pandemic was determined to be effective on the students' thoughts of "disagreeing" with a negative opinion towards their career goals. In terms of a negative viewpoint towards their career goals, the probability of a student "disagreeing" with this view rather than strongly agreeing is 3.819 and 3.798 times higher, respectively, for those who do not have the fear of pandemic and those who sometimes do, compared to those who express that they always have this fear.

\section{Conclusion}

Considering their highly important position for the future of the whole world, the university youth's awareness of their prospective targets and their implementation efforts have been a study subject for many researchers. This study attempted to determine whether the fear and uncertainty caused by the Covid-19 pandemic affecting a serious population all around the world had an impact on the university students' career goals. Prepared by obtaining the required ethics committee approvals in accordance with the designated purpose, the questionnaire form was applied online, and 352 returns were received. As a result of the analyses conducted, the following findings have been obtained.

$34.4 \%$ of the students who participated in the survey were male and $65.6 \%$ were female students. $58.8 \%$ of these students were between the ages of 18-20, while $32.1 \%$ were between $21-23$. According to the types of education, $71.3 \%$ of the students were associate degree students and $28.7 \%$ were undergraduate and graduate students. While $29.5 \%$ of the students stated that they never had the fear of pandemic, $56.5 \%$ of them stated that they sometimes had the fear of pandemic and $13.9 \%$ of them stated that they always had the fear of pandemic. A statistically significant relationship appeared between the education level, program, and the fear of pandemic, which were taken as independent variables, and CGF. Subsequent to the multinomial logistic regression analysis, the results revealed that only the fear of pandemic had an impact on CGF. Following the analysis, it was found that the students 
who sometimes had the fear of pandemic and those who never had were more likely to disagree with a negative opinion about CGF compared to those who always had the fear of pandemic. The analysis conducted shows that the fear of pandemic experienced by the students negatively affects their career goals. The fact that the subject dealt with in our study was related to the pandemic period, thus the data had to be collected in a limited time, and the research, unfavorably, did not cover a wider area concerning the university students' programs appear to be the most important constraint.

The research results show that the career goal feedbacks of the students who are afraid of the pandemic are negatively affected. Negative feedbacks could cause the students to reconsider their career goals and abandon them. In order to eliminate the negative feedback, it could be recommended that universities provide career counseling and psychological counseling to students. The study by $\mathrm{Hu}$, Creed and Hood (2017) shows that internal and external factors would affect career goals both positively and negatively. Therefore, due to the similarity revealed in this study, it is evaluated that the fear of the pandemic negatively affects students both internally and externally. For students to overcome the fear of the pandemic that is emerging today, various support activities for their academic self-efficacy and social competence should be in question. The results obtained by Dönmez and Gürbüz (2020) reveal that the authorities stand out as the most important source of trust regarding the pandemic. Considering this finding, we can state that the authorities have an important role in eliminating the negative effect of the fear of the pandemic on students' career goal feedbacks, which is revealed in our study. The multi-author book titled Covid-19 Pandemisinin Ekonomik, Toplumsal ve Siyasal Etkileri [Economic, Social and Political Effects of the Covid-19 Pandemic], edited by Demirbaş, Bozkurt and Yorğun in 2020 is also an important guide especially for the precautions to be taken and things to do. Ultimately, as a result of the findings obtained in our study, the negative feedback on career goals caused by anxiety and stress in young people can be eliminated by enabling young people to evaluate new possibilities that will arise with the development of technology and providing psychological support services, as expressed in the 
aforementioned book. Considering all these circumstances, this research will make a considerable contribution to the literature as it covers the pandemic period.

Ethics Statement: The authors declare that ethical rules are followed in all preparation processes of this study. In case of detection of a contrary situation, BIİBFAD Journal does not have any responsibility and all responsibility belongs to the authors of the study. Ethical approval for this study was obtained from Kocaeli University Humanities and Social Sciences Research Ethics Committee (Date: 24.07.2020 / No: 52506)

Author Contributions: 1st author's contributed to the determination of the subject, literature, collecting of data and reporting sections. 2nd author's contributed to the literatüre, collection of, data analysis and reporting. 1st author's contribution rate is approximately $50 \%$, 2 nd author's contribution rate is $50 \%$.

Conflict of Interest: There is no conflict of interest between the author.

Acknowledgement: We would like to thank the Editorial Board of BIIBBFAD Journal for their intense interest and efforts and the referees for their contribution.

\section{References}

Akdoğanlı, Ç. (2019). Algılanan Kariyer Bariyerleri: Kadın Çalışanlar Üzerine Bir Araştırma İstanbul Üniversitesi, Sosyal Bilimler Enstitüsü, Yayınlanmamış Yüksek Lisans Tezi, İstanbul.

Arı, E. (2016). Bireylerin umut düzeyleri ile gelecek hakkındaki düşünceleri arasındaki ilişkinin multinominal lojistik regresyon analizi ile incelenmesi. Dumlupınar Üniversitesi Sosyal Bilimler Dergisi, 47, 184-194.

Aşkın R., Bozkurt Y., \& Zeybek Z., (2020). Covid-19 pandemisi: psikolojik etkileri ve terapötik müdahaleler. İstanbul Ticaret Üniversitesi Sosyal Bilimler Dergisi Covid-19 Sosyal Bilimler Özel Sayısı, 19(37), 304-318.

Baltacı, Ö., Akbulut, Ö.F., \& Zafer, R. (2020). COVID-19 pandemisinde problemli internet kullanımı: bir nitel araştırma. Kırşehir Ahi Evran Üniversitesi Sağlık Bilimleri Enstitüsü Dergisi, 1(3), 126-140. 
Bandura, A. (1991). Social cognitive theory of self-regulation. Organizational Behaviour and Human Decision Processes, 50, 248287.

Bayram, N. (2004). Multinominal lojistik regresyon analizinin istihdamdaki işgücüne uygulanması. İstanbul Üniversitesi İktisat Fakültesi Mecmuası, 54(2), 61-75

Budak, F. \& Korkmaz, Ş. (2020). Covid-19 pandemi sürecine yönelik genel bir değerlendirme: Türkiye örneği. Sosyal Araştırmalar ve Yönetim Dergisi, (1), 62-79.

Butler, D.L. \& Winne, P.H. (1995). Feedback and self-regulated learning: A theoretical synthesis. Review of Educational Research, $65,245-281$.

Byrnes, Y. M., Civantos, A. M., Go, B. C., McWilliams, T. L., \& Rajasekaran, K. (2020). Effect of the COVID-19 pandemic on medical student career perceptions: a national survey study. Medical Education Online, 25(1), 1798088.

Çetin, C. \& Anuk, Ö. (2020). Covid-19 pandemi sürecinde yalnızlık ve psikolojik dayanıklılık: bir kamu üniversitesi öğrencileri örneklemi. Avrasya Sosyal ve Ekonomi Araştırmaları Dergisi, Covid-19 Özel Sayısı 2, 170-189.

Demirbaş, D., Bozkurt, V.\& Yorğun, S. (2020). Covid-19 Pandemisinin Ekonomik, Toplumsal ve Siyasal Etkileri. İstanbul Üniversitesi Yayınevi, İstanbul

Dönmez, İ. \& Gürbüz, S. (2020). Üniversite öğrencilerinin covid-19 virüsü hakkında bilişsel yapılarının belirlenmesi. MANAS Sosyal Araştırmalar Dergisi, 9 (4), 2159-2172.

Ertürk, M. (2011). İnsan Kaynaklarn Yönetimi. Beta Yayınları, İstanbul.

Gonzalez, T., de la Rubia, M.A., Hincz, K.P., Comas-Lopez, M., Subirats, L., Fort, S., et al. (2020). Influence of COVID-19 confinement on students' performance in higher education. PloS one 15(10): e0239490.

Hattie, J. \& Timperley, H. (2007). The power of feedback. Review of Educational Research, 77(1), 81-112. 
Hu, S., Creed, P.A., \& Hood, M. (2017). Development and initial validation of a measure to assess career goal feedback. Journal of Psychoeducational Assessment, 35(7) 657-669.

Hu, S., Hood, M., \& Creed, P.A. (2018a). Negative career feedback and career outcomes: Mediation roles of self-regulation processes. Journal of Vocational Behavior, 106(6), 180-191.

Hu, S., Hood, M., \& Creed, P.A. (2018b). Within-person relationship between career goal feedback and career-related stress: A weekly survey study. Journal of Counseling Psychology, 65(6), 681-689.

Hu, S., Hood, M., Creed P.A. (2016). Career goal importance as a moderator in the relationship between career feedback and career-related stress. Journal of Career Development, 45(1),3-18.

Islam, M.A., Barna, S.D., Raihan, H., Khan, M.N.A., Hossain, M.T. (2020). Depression and anxiety among university students during the COVID-19 pandemic in Bangladesh: A web-based cross-sectional survey. PloS One, 15(8), e0238162.

Jawahar, I.M. \& Shabeer, S. (2019). How does negative career feedback affect career goal disengagement? the mediating roles of career planning and psychological well-being. Journal of Career Development, 41(6), 24-42

Kalayc1, Ş. (2009). SPSS Uygulamah Çok Değişkenli İstatistik Teknikleri. Asil Yayın Dağıtım, 4. Baskı [4 ${ }^{\text {th }}$ ed.], Ankara

Kaynak, T. et al., (2000). İnsan Kaynakları Yönetimi. İstanbul Üniversitesi İşletme İktisadı Enstitüsü Araştırma ve Yardım Vakfı Yayını, No: 7, 2. Bask1 [2nd ed.]. İstanbul.

Korkmaz, O. \& Kırdök, O. (2019). Kariyer hedefi geribildirim ölçeği'nin (KHGÖ) Türkçeye uyarlanması: geçerlik ve güvenirlik çalışması. Journal of Theoretical Educational Science, 12 (2), 494-510.

Mavisu, H. (2010). Bireysel Kariyer Planlamanın Aşamalarından Biri Olarak Hedef Belirleme ve Kariyer Başarısı İlişkisi. Dokuz 
Eylül Üniversitesi, Sosyal Bilimler Enstitüsü, Yayınlanmamış Yüksek Lisans Tezi, İzmir.

Nicola, M., Alsafi, Z., Sohrabi, C., Kerwan, A., Al-Jabir, A., Iosifidis, C., Agha, M., \& Agha, R. (2020). The socio-economic implications of the coronavirus pandemic (COVID-19): A review. International Journal of Surgery, 78, 185-193.

Sabuncuoğlu, Z. (2008). İnsan Kaynakları Yönetimi. Alfa Aktüel Basım, Bursa.

https://www.who.int/health-topics/coronavirus\#tab=tab_3.

Zajas, J.J. \& Zajas, J.R.M. (1994) Planning your total career and life portfolio: Part 1: A model for management development. Librarian Career Development, 2(3), 7-10.

Zhang, D., Hu, M., \& Ji, Q. (2020). Financial markets under the global pandemic of COVID-19, Finance Research Letters, 36(10), 101528. 